\title{
Analisis Kemampuan Berpikir Kritis Siswa SMA Kelas X MIPA dalam Pembelajaran Fisika
}

\author{
Rian Priyadi, Amin Mustajab, Mohammad Zaky Tatsar, Sentot Kusairi \\ rianpriyadi94@gmail.com \\ Pendidikan Fisika-Pascasarjana Universitas Negeri Malang \\ Jl Semarang 5, Malang
}

\begin{abstract}
Abstrak - Penelitian ini bertujuan mendeskripsikan kemampuan berpikir kritis siswa X MIPA disalah satu SMA Negeri di Kabupaten Pelalawan. Jenis penelitian ini adalah penelitian deskriptif dengan pendekatan kualitatif. Penelitian ini dilaksanakan pada siswa kelas X MIPA $(N=32)$ dengan mengerjakan tes kemampuan berpikir kritis yang diadaptasi dari Erceg et al.[1] pada materi hukum gerak Newton dengan mengunakan dua kategori utama yakni evaluasi dan inferensi. Hasil penelitian menunjukan kemampuan berpikir kritis siswa tergolong masih rendah pada kategori evalusi. Siswa hanya mampu menyelesaikan perhitungan fisikanya namun tidak mampu menghubungkan konsep fisika dengan keadaan sebenarnya, sehingga akan berdampak pada hasil belajar siswa. Oleh karena itu, mencari penyebab rendahnya kemampuan berpikir kritis siswa dan pengembangan model pembelajaran yang dapat mengembangkan kemampuan berpikir kritis siswa sangat disarankan.
\end{abstract}

Kata Kunci: kemampuan berpikir kritis, hukum gerak Newton

\section{PENDAHULUAN}

Perkembangan ilmu pengetahuan, teknologi, dan informasi pada abad ke-21 membutuhkan sumberdaya manusia yang memiliki kemampuan berpikir kritis [3],[4],[5]. Berpikir kritis diperlukan untuk memeriksa kebenaran dari suatu informasi, sehingga dapat memutuskan informasi tersebut layak diterima atau ditolak $[3],[6],[7]$. Selain itu, siswa yang mampu berpikir kritis akan mampu menyelesaikan masalah secara efektif [8],[9],[10].

Menurut Ennis [11], berpikir kritis adalah berpikir logis dan reflektif yang difokuskan pada pengambilan keputusan yang akan dilakukan, berpikir kritis merupakan bagian yang tidak bisa dipisahkan dari pendidikan dan berpikir kritis merupakan kemampuan kognitif yang sangat penting [12]. Berpikir kritis mencakup dua hal, yaitu kemampuan berpikir kritis (critical thinking ability) dan disposisi berpikir kritis (critical thinking disposition) [11]. Kemampuan (ability) merujuk pada aspek kognitif dan disposisi (disposition) merujuk pada aspek afektif [13].

Kategori kemampuan berpikir kritis meliputi interpretasi, analisis, evaluasi, inferensi, eksplanasi, dan regulasi diri [2]. Dari enam kategori tersebut, penelitian ini akan mengukur dua kategori kemampuan berpikir kritis yakni evaluasi dan inferensi. Evaluasi merupakan kemampuan pemaknaan dari representasi hasil yang diperoleh, sedangakan inferensi adalah kemampuan dalam mengidentifikasi informasiinformasi yang dibutuhkan untuk menarik kesimpulan. Dalam melakukan evaluasi sangat diperlukan pemikiran yang reflektif dan pada inferensi diperlukan pemikiran yang logis $[8],[9],[14]$.
Penelitian ini bertujuan untuk mendeskripsikan kemampuan berpikir kritis siswa berdasarkan kategori evaluasi dan inferensi dengan menggunakan instrumen tes yang diadaptasi dari Erceg et al. [1]. Dengan adanya penelitian ini, diharapkan dapat memberikan informasi dan gambaran kepada pendidik fisika tentang kondisi kemampuan berpikir kritis siswa, sehingga guru dapat merancang kegiatan pembelajaran yang dapat mengajak siswa untuk melatih kemampuan berpikir kritisnya.

\section{METODOLOGI PENELITIAN}

Jenis penelitian ini adalah penelitian deskriptif dengan pendekatan kualitatif. Tujuan utama dari penelitian deskriptif adalah untuk memberikan gambaran yang akurat atau karakteristik dari situasi atau fenomena ${ }^{[15]}$. Subjek penelitian ini adalah siswa kelas $X$ MIPA disalah satu SMA di Kabupaten Pelalawan $(N=32)$.

Prosedur penelitian ini yaitu: tahap pralapangan, tahap pekerjaan lapangan, dan tahap analisis data. Kegiatan yang dilakukan tahap pra-lapangan adalah meminta ijin kepada pihak sekolah dan menyusun instrumen penelitian. Kegiatan yang dilakukan pada tahap pekerjaan lapangan adalah memberikan tes kemampuan berpikir kritis kepada siswa. Sedangkan pada tahap analisis data kegiatan yang dilakukan adalah menganalisis hasil tes.

Instrumen yang digunakan dalam penelitian ini adalah tes kemampuan berpikir kritis yang diadaptasi dari Erceg et a/[1] terdiri dari dua soal esai pada materi hukum gerak Newton. Pemilihan instrumen ini dikarenakan diperlukan analisis mendalam sehingga tidak hanya sekedar menggunakan rumus fisika dalam proses 
penyelesaiannya. Soal-soal ini memungkinkan siswa untuk memahami, menganalisis, mengevaluasi dan menyimpulkan hasil penyelesaian.

Data yang diperoleh kemudian dianalisis dengan 3 kriteria yakni; jawaban benar, jawaban salah, dan tidak menjawab. Sedangkan kategori berpikir kritis siswa dianalisis menggunakan kategori keterampilan berpikir kritis yang diadaptasi dari Facione ${ }^{[2]}$ yang terdiri dari evaluasi dan inferensi.

\section{HASIL DAN PEMBAHASAN}

Tes kemampuan berpikir kritis yang digunakan untuk mengambil data terdiri dari dua masalah fisika pada materi hukum gerak newton. Hasil tes tersebut diperoleh data berupa hasil jawaban siswa yang ditunjukan pada Gambar 1.

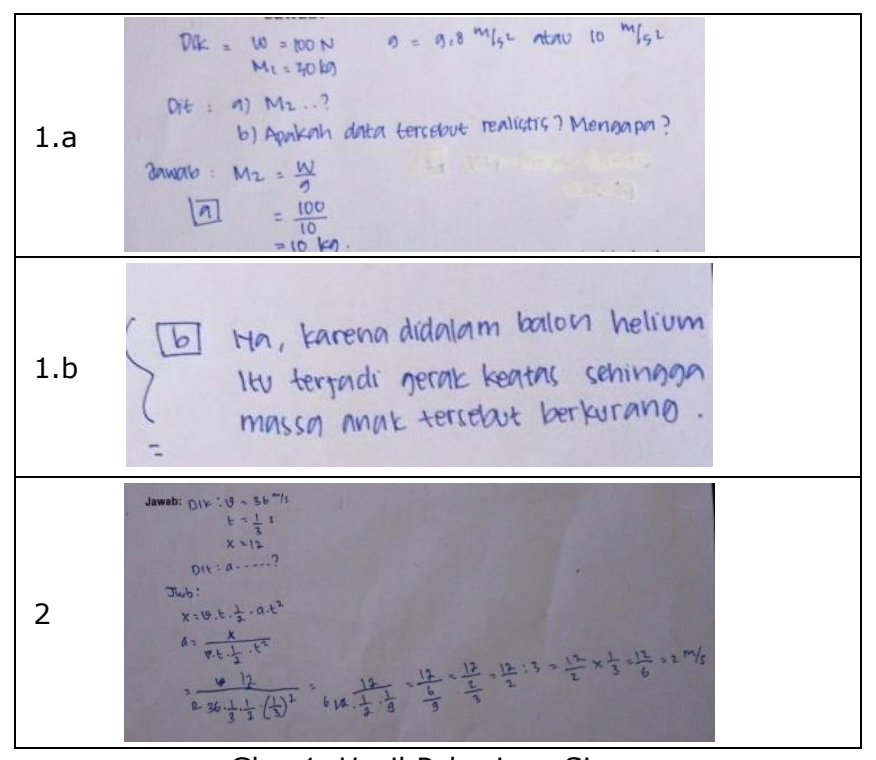

Gbr. 1. Hasil Pekerjaan Siswa

Berdasarkan hasil jawaban siswa tersebut, selanjutnya dianalisis menggunakan kriteria dan kategori yang telah ditentukan. Hasil tes siswa diperoleh sebaran data seperti pada Tabel 1 berikut.

\begin{tabular}{llc}
\multicolumn{3}{c}{ TABEL 1. SEBARAN JAWABAN SISWA } \\
\hline Nomor Soal & Keterangan & Persentase \\
\hline $1 . a$ & Jawaban Benar & $56 \%$ \\
& Jawaban Salah & $44 \%$ \\
\multirow{4}{*}{.b } & Tidak Menjawab & $0 \%$ \\
& Jawaban Benar & $0 \%$ \\
2 & Jawaban Salah & $100 \%$ \\
& Tidak Menjawab & $0 \%$ \\
& Jawaban Benar & $0 \%$ \\
& Jawaban Salah & $93 \%$ \\
& Tidak Menjawab & $7 \%$
\end{tabular}

Tabel 1 menunjukan siswa hanya mampu menyelesaian persoalan fisika melalui perhitungan (soal 1.a) namun tidak mampu menghubungkan konsep fisika dengan keadaan sebenarnya (soal 1.b dan 2). Penelitian serupa yang dilakukan oleh Erceg et al [1] pada siswa kejuruan di Kroasia menghasilkan temuan bahwa pemikiran kritis siswa yang rendah dikarenakan siswa terbiasa dengan konsep fisika dan tidak terbiasa menerapkan konsep fisika dalam kehidupan nyata.

Rendahnya kemampuan berpikir kritis siswa pada permasalahan ini disebabkan oleh beberapa hal, diantaranya (1) siswa mengalami kesulitan dalam menyelesaikan dan menjawab pertanyaan yang diberikan, (2) siswa mengalami kesulitan dalam mengidentifikasi persamaan ketika meyelesaikan permasalah terkait dengan hukum gerak newton dan (3) siswa mengalami kesulitan dalam menghubungkan hasil perhitungan dengan fenomena yang sesungguhnya. Beberapa penelitian menunjukkan bahwa kesulitan, miskonsepsi, dan kurangnya pemahaman yang dialami dan dimiliki oleh siswa pada materi hukum gerak Newton diindikasi salah satunya berasal dari kemampuan berpikir kritis yang rendah $[16],[17],[18]$.

Rendahnya kemampuan berpikir kritis pada siswa dapat disebabkan oleh beberapa faktor. Salah satunya, ketika siswa datang dalam suatu kelas sebenarnya tidak membawa pengetahuan yang kosong atau pikiran yang kosong, namun mereka memiliki pengetahuan yang terpotongpotong, sehingga siswa mengalami kesulitan ketika mengaitkan suatu konsep satu sama lain [19],[20]. Kebiasaan belajar siswa juga menyebabkan kemampuan berpikir kritis tidak berkembang, siswa lebih cenderung sudah merasa nyaman dengan penjelasan dari guru tanpa mempertanyaakan lebih dalam.

\section{KESIMPULAN}

Penelitian ini menyelidiki sikap kritis siswa terhadap pertanyaan masalah fisika dan keberagaman solusi dalam menyelesaikan masalah fisika. Hasil penelitan menunjukan $56 \%$ siswa dapat menyelesaikan perhitungan fisika. Namum, siswa mengalami kesulitan dalam memaknai data yang diberikan.

Dari analisis ini dapat disimpulkan bahwa kemampuan berpikir kritis siswa tergolong masih rendah pada kategori evalusi. Ditemukan bahwa siswa hanya mampu menyelesaikan perhitungan fisika (inferensi) tetapi tidak mampu memaknai jawabannya (evaluasi). Siswa mengalami kesulitan dalam mengidentifikasi asumsi yang salah dan mengidentifikasi data yang tidak diberikan pada saat pemecahan masalah

Masalah semacam ini bisa diperbaiki melalui pegajaran fisika yang berkenaan dengan tujuan mengembangkan kompetensi siswa dalam kehidupan nyata. Hal ini dapat meningkatkan kesadaran guru tentang pentingnya 


\section{Jurnal Pendidikan Fisika Tadulako Online (JPFT) \\ Vol. 6 No. 1 \\ p-ISSN 2338-3240, e-ISSN 2580-5924}

mengembangkan sikap kritis siswa dalam menghadapi permasalahan. Selain itu pemahaman konsep yang tidak terpotongpotong juga menjadi salah satu yang perlu diperhatikan dalam proses pembelajaran.

Keterbatasan penelitian ini terletak pada sedikitnya jumlah item soal yang digunakan untuk menyimpulkan poses berpikir kritis siswa. Untuk penelitian selanjutnya perlu dicari penyebab rendahnya kemampuan berpikir kritis siswa dan mengembangan model pembelajaran yang dapat meningkatkan kemampuan berpikir kritis siswa.

\section{DAFTAR PUSTAKA}

[1] N. Erceg, I. Aviani, and V. Mešić, "s," Rev. Mex. Fis. E, vol. 59, no. 1, pp. 65-76, 2013

[2] P. A. Facione, Critical Thinking: What It Is and Why It Counts, no. ISBN 13: 978-1-891557-07-1. 2011.

[3] F. Kalelioğlu and Y. Gülbahar, "The Effect of Instructional Techniques on Critical Thinking and Critical Thinking Dispositions in Online Discussion," $J$. Educ. Technol. Soc., vol. 17, no. 1, pp. 248-258, 2014.

[4] E. Aizikovitsh-udi and D. Cheng, "Developing Critical Thinking Skills from Dispositions to Abilities: Mathematics Education from Early Childhood to High," Creat. Educ., vol. 6, no. March, pp. 455-462, 2015.

[5] C. Kriel, "Creating a disposition for critical thinking in the mathematics classroom .," in Proceedings of the 2nd Biennial Conference of the South African Society for Engineering Education, 2013, pp. 67-75.

[6] D. Haryani, "Pembelajaran Matematika Dengan Pemecahan Masalah," Pros. Semin. Nas. Penelitian, Pendidik. dan Penerapan MIPA, no. 1980, pp. 121-126, 2011.

[7] A. R. As'ari, "Ideas for Developing Critical Thinking at Primary School Level," Int. Semin. Addressing High. Order Think. Crit. Think. Issues Prim. Educ., no. March, pp. 1-13, 2014.

[8] L. G. Snyder and M. J. Snyder, "Teaching Critical
Thinking and Problem Solving Skills," Delta Pi Epsil. J., vol. 50, no. 2, pp. 90-99, 2008.

[9] E. E. Peter, "Critical thinking: Essence for teaching mathematics and mathematics problem solving skills," African J. Math. Comput. Sci. Res., vol. 5, no. 3, pp. 39-43, 2012.

[10] A. N. Chukwuyenum, "Impact of critical thinking on performance in mathematics among senior secondary school students in Lagos State," IOSR J. Res. Method Educ., vol. 3, no. 5, pp. 18-25, 2013.

[11] R. H. Ennis, "The Nature of Critical Thinking: An Outline of Critical Thinking Dispositions," Univ. Illinois, pp. 1-8, 2011.

[12] Q. Zhou, Q. Huang, and H. Tian, "Developing Students' Critical Thinking Skills by Task-Based Learning in Chemistry Experiment Teaching," Creat. Educ., vol. 4, no. 12, pp. 40-45, 2013.

[13] R. M. Vieira, C. Tenreiro-Vieira, and I. P. Martins, "Critical thinking: Conceptual clarification and its importance in science education," Sci. Educ. Int., vol. 22, no. 1, pp. 43-54, 2011.

[14] V. R. Ruggiero, Beyond Feelings A Guide to Critical Thinking, 9th ed. New York: McGraw-Hill, 2012.

[15] B. Johnson and L. Christensen, Educational Research: Quantitative, Qualitative, and Mixed Approaches, 2nd ed. United Stated of America: Pearson Education, 2004.

[16] C. Teck Chee, "Common Misconceptions in Frictional Force among University Physics Students," Teach. Learn., vol. 16, no. 2, pp. 107-116.

[17] L. Eraikhuemen and A. Ogumogu, "An assessment of secondary school physics teachers conceptual understanding of force and motion in Edo," vol. 5, no. 1, pp. 253-262, 2014.

[18] P. B. Kohl and N. D. Finkelstein, "Patterns of multipe representation use by experts and novices during physics problem solving," Phys. Rev. Spec. Top. - Phys. Educ. Res., vol. 4, no. 1, pp. 1-13, 2008.

[19] J. L. Docktor and J. P. Mestre, "Synthesis of disciplinebased education research in physics," Phys. Rev. Spec. Top. - Phys. Educ. Res., vol. 10, no. 2, pp. 1-58, 2014.

[20] S. D. Ivie, "Metaphor: A model for teaching critical thinking," Contemp. Educ., vol. 72, no. 1, pp. 18-22, 2001. 